\title{
Study on the Corrosion Resistance of Galvannealed Coatings on Different Alloying Parameters
}

\author{
Xunhua Yuan ${ }^{1,}$, Qifu Zhang ${ }^{1, b}$ \\ ${ }^{1}$ National Engineering Laboratory of Advanced Coating Technology for Metals, Central Iron \& Steel \\ Research Institute, Beijing, 100081, China \\ axhyuan092@sina.com, bzhqifu@sina.com
}

Keywords: High strength IF steel, Galvannealed coating, Galvannealed process, Fe content, Corrosion resistance

\begin{abstract}
The galvannealed coating with different Fe contents were prepared by controlling the galvannealed process parameters of hot-dip galvanized high-strength IF steel sheet, and analyzed the influence of Fe contents on the corrosion resistance of galvannealed coating. The results show that the corrosion resistance of galvannealed coating increased with the Fe content, and it was also influenced by the phase structure and the proportion of different phases in the galvannealed coating. At the same galvannealed temperature, along with the prolongation of galvannealed time, the initiative corrosion potential of galvannealed coating changed little. The compact $\Gamma_{1}$ phase in galvannealed coating could improve the corrosion resistance effectively. At the same galvannealed time, the corrosion resistance of galvannealed coating was better, when the galvannealed temperature was higher.
\end{abstract}

\section{Introduction}

Corrosion potential of hot dip galvannealed coating was rested with the balance potential of $\mathrm{Fe}$ and $\mathrm{Zn}$. The zinc has the low site in the EMF [1,2], and it would result in more positive corrosion potential. The change way of corrosion potential and corrosion rate of zinc alloy is very complex in the galvannealed coating, it was not only influenced by Fe contents [3], but also influenced by the intermetallic phase and alloy fine texture [4-6]. This article aims on analyzing the corrosion resistance of galvannealed coating with different $\mathrm{Fe}$ contents, which was prepared in different galvannealed processing parameters. It was important to make sure the influence rule of galvannealed processing parameters to the corrosion resistance of galvannealed coating. This article researched the change rule of corrosion potential, corrosion current and corrosion rate of the high-strength IF galvannealed coating with different Fe contents, which prepared through change the galvannealed temperature and galvannealed time.

\section{Experimental Material and Method}

Experimental Material. Experimental material was hot-dip galvanized high-strength IF steel sheet, thickness was $0.8 \mathrm{~mm}$, galvanized coating weight was $45 \mathrm{~g} / \mathrm{m}^{2}$ in the single-sided, the composition of hot-dip high-strength IF steel sheet was shown in Table 1. Cut the plate to the same specs according to the experimental request, washed and dried in the air.

Table 1. The composition (wt.\%) of hot-dip galvanized high-strength IF steel sheet.

\begin{tabular}{ccccccc}
\hline $\mathrm{Mn}$ & $\mathrm{C}$ & $\mathrm{S}$ & $\mathrm{Al}$ & $\mathrm{Ti}$ & $\mathrm{Si}$ & $\mathrm{P}$ \\
\hline 0.50 & 0.005 & 0.008 & 0.028 & 0.023 & 0.094 & 0.055 \\
\hline
\end{tabular}

Experimental Method. A set of samples was heated to $450{ }^{\circ} \mathrm{C}$ in an induction heating furnace at a heating rate of $10{ }^{\circ} \mathrm{C} / \mathrm{s}$, and keeping 120s, 150s, 240s, 300s and 360s respectively; another set of samples was heated to $500{ }^{\circ} \mathrm{C}$ at the same heating rate, and keeping 60s, 90s, 120s, 150s and 180s 
respectively; the third set of samples was heated to $550{ }^{\circ} \mathrm{C}$ at the same heating rate, and keeping $5 \mathrm{~s}$, $10 \mathrm{~s}, 15 \mathrm{~s}, 20 \mathrm{~s}$ and $25 \mathrm{~s}$ respectively, then quenched with water and dried in the air.

The influence of galvannealed processing parameters on the corrosion resistance of galvannealed coating was analyzed by electrochemical method. Polarization curve of galvannealed coating were measured by Galvanostat Moldel 273. Electrolytic experiment using three electrodes system, reference electrodes were saturated calomel electrode (SCE), auxiliary electrodes was platinum electrode, electrolyte was $200 \mathrm{~g} / \mathrm{l} \mathrm{NaCl}$ solution, chose the linear sweep voltammetry, made the potential scope as $-0.1 \sim 0.1 \mathrm{~V}$, the scanning velocity was $25 \sim 50 \mathrm{mV} / \mathrm{s}$, scanning gap was $0.002 \mathrm{~V}$, use the galvannealed plate samples as the working electrode, weathered it after scraping with acetone. Used the wax to seal up all the samples except an area about $1 \mathrm{~cm}^{2}$ in one surface. After measuring the area, and input it into the experimental parameters.

Input the current density and the voltage data in the experiment into ORIGIN and drew the chart after current logarithm conversion. According to the electrochemical theory, the two beeline parts of positive pole polarization curve and negative pole polarization curve can intersect one point; the abscissa of the point is the logarithm of corrosion current density. The vertical axis of the point is self-corrosion voltage. The relationship of corrosion rate and corrosion current density is as the formula (1).

$$
v=\frac{M}{n F} \cdot i_{\text {corr }}=3.73 \times 10^{-4} \frac{M}{n} \cdot i_{\text {corr }}
$$

where, the $\mathrm{v}$ is corrosion rate $\left(\mathrm{g} / \mathrm{m}^{2} \cdot \mathrm{h}\right)$, icorr is self-corrosion current density $\left(\mathrm{mA} / \mathrm{cm}^{2}\right), \mathrm{M}$ is the mole mass of galvannealed coating, $\mathrm{n}$ is the valence of galvannealed coating.

\section{Experimental Results and Analysis}

Influence of the Galvannealed Processing Parameters. When the galvannealed temperature was $450{ }^{\circ} \mathrm{C}$, the galvannealed time was $120 \mathrm{~s}, 150 \mathrm{~s}, 240 \mathrm{~s}, 300 \mathrm{~s}$ and $360 \mathrm{~s}$ respectively, the result of electrochemical analysis was shown in Fig. 1 (a). As can be seen from Fig. 1 (a) that when the galvannealed temperature was $450{ }^{\circ} \mathrm{C}$, along with the prolongation of galvannealed time, the corrosion potential increased, corrosion rate decreased, and corrosion resistance increased.

The phase structure of galvannealed coating that galvannealed at $450{ }^{\circ} \mathrm{C}$ was shown in Fig. 2, from Fig. 1 (a) and Fig. 2 can be see that the corrosion resistance of galvannealed coating was related to the phase structure in the coating, along with the prolongation of galvannealed time, the phase structure of galvannealed coating would be change. From Fig. 2 can been see that along with the prolongation of galvannealed time, the phase structure in galvannealed coating was changed as: $\eta \rightarrow \eta+\zeta \rightarrow \eta+\zeta+\delta_{1 \mathrm{p}}+\delta_{1 \mathrm{k}} \rightarrow \zeta+\delta_{1 \mathrm{p}}+\delta_{1 \mathrm{k}}$. When the galvannealed time were $120 \mathrm{~s}$ and $150 \mathrm{~s}$, the galvannealed coating were all comprised by $\eta$ phase which elbowed prismatical $\zeta$ phase with order orientation. However, when the galvanealed time was $120 \mathrm{~s}$, the galvanealed coating was mainly comprised by $\eta$ phase and a little $\zeta$ phase, and the ratio of $\zeta$ phase in galvannealed coating was increased obviously, when the galvannealed time was $150 \mathrm{~s}$. The electrochemical theory showed that single phase structure had better corrosion resistance than the polyphase structure. From Fig. 1 (a), the corrosion potential had little descend, when the galvannealed time was $120 \mathrm{~s}$ and $150 \mathrm{~s}$.

When the galvannealed time was $240 \mathrm{~s}$ and $300 \mathrm{~s}$, there were a lot of columnar crystals $\delta_{1 \mathrm{p}}$ phase which perpendicular to the steel substrate and the coating interface approximately at coating section near the surface, but at the site near steel substrate, there were some random orientation connected $\delta_{1 \mathrm{k}}$ phase and some $\eta$ and $\zeta$ phase. Because corrosion potential of $\mathrm{Zn}-\mathrm{Fe}$ alloy rested with the balance potential of zinc and iron, Zinc has the low site in the EMF, it will result in more positive corrosion potential galvannealed with lots of elements. Little Fe cannot change the pure zinc corrosion potential obviously as usual before it achieve a certain value, and the corrosion resistance of galvannealed coating will change obviously after it achieve a certain value. When the coating were mainly comprised by $\delta_{1}$ phase, the Fe content was about $7.0 \sim 11.5$ wt. $\%$, more than $6.0 \sim 6.2$ wt. $\%$ ( $\zeta$ phase) and $0 \sim 0.003$ wt. $\%$ ( $\eta$ phase). So the corrosion potential and corrosion resistance of 
galvannaeled coating were increased and corrosion rate was descended. When the galvannealed time was $360 \mathrm{~s}$, the columnar crystals $\delta_{1 \mathrm{p}}$ phase were disappeared entirety, and all coating section was occupied by compact $\delta_{1 \mathrm{k}}$ phase. At this time, the corrosion resistance of galvannealed coating was increased obviously.

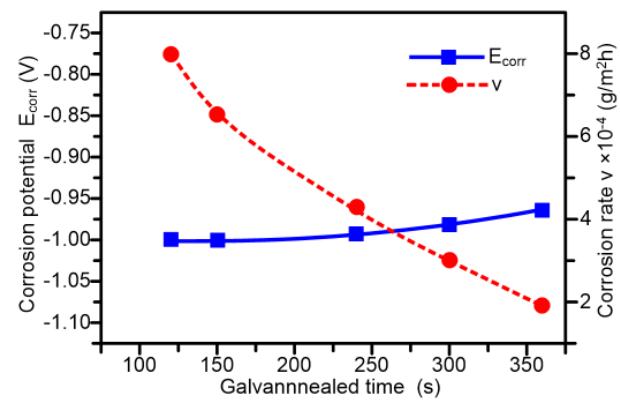

(a) $450{ }^{\circ} \mathrm{C}$

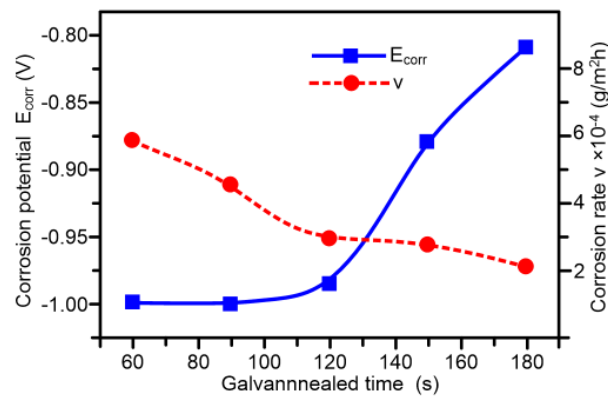

(b) $500{ }^{\circ} \mathrm{C}$

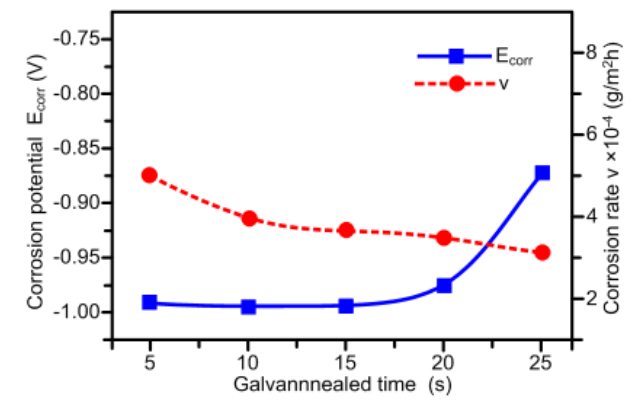

(c) $550{ }^{\circ} \mathrm{C}$

Fig. 1 The relationship of corrosion potential, corrosion rate and galvannealed time, (a) $450{ }^{\circ} \mathrm{C}$, (b) $500{ }^{\circ} \mathrm{C}$, (c) $550{ }^{\circ} \mathrm{C}$.

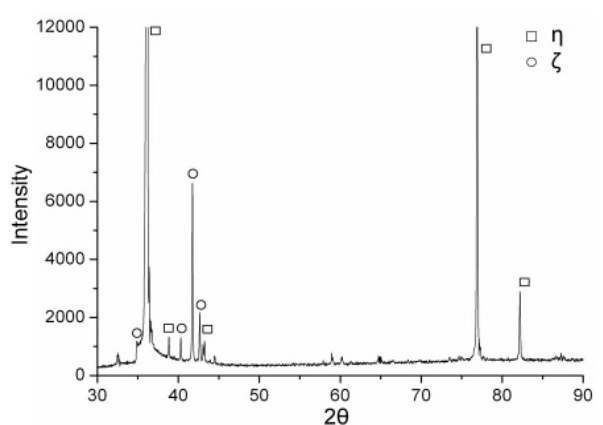

(a) $120 \mathrm{~s}$

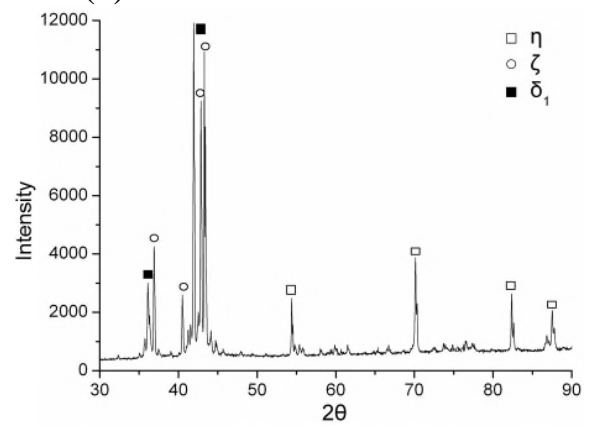

(d) $240 \mathrm{~s}$

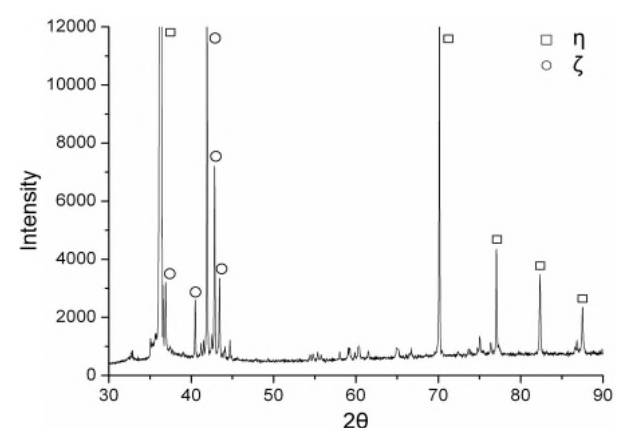

(b) $150 \mathrm{~s}$

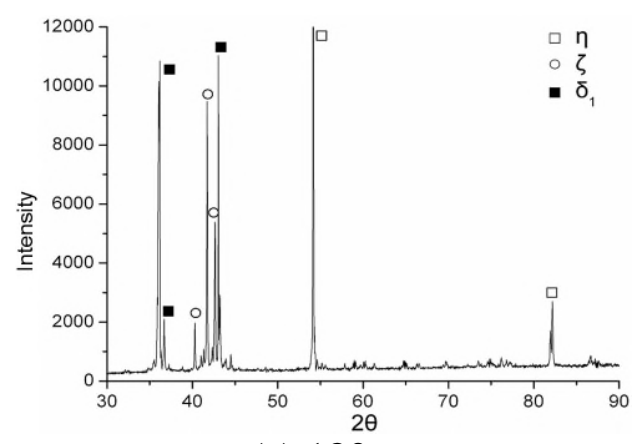

(c) $180 \mathrm{~s}$

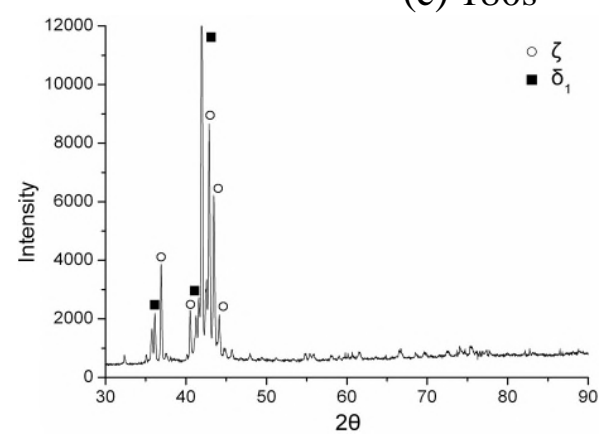

(e) $360 \mathrm{~s}$

Fig. $2 \mathrm{X}$-ray diffraction patterns of different phases structure in galvannealed coating with different galvannealed time at $450{ }^{\circ} \mathrm{C}$ (a) $120 \mathrm{~s}$, (b) $150 \mathrm{~s}$, (c) $180 \mathrm{~s}$, (d) 240s, (e) $360 \mathrm{~s}$.

When the galvannealed temperature was $500^{\circ} \mathrm{C}$, the galvannealed time was $60 \mathrm{~s}, 90 \mathrm{~s}, 120 \mathrm{~s}, 150 \mathrm{~s}$ and 180s respectively, the result of electrochemical analysis was shown in Fig. 1 (b). As can be seen from Fig. 1 (b) that along with the prolongation of galvannealed time, self-corrosion potential increased from $-0.999 \mathrm{~V}$ to $-0.809 \mathrm{~V}$, corrosion rate descended from $5.85 \times 10^{-4} \mathrm{~g} / \mathrm{m}^{2} \mathrm{~h}$ to $2.98 \times 10^{-4}$ $\mathrm{g} / \mathrm{m}^{2} \mathrm{~h}$, so when the galvannealed temperature was $500{ }^{\circ} \mathrm{C}$, the corrosion resistance of high strength IF steel galvannealed coating was increased with the increase of galvannealed time.

The phase structure of galvannealed coating that galvannealed at $500{ }^{\circ} \mathrm{C}$ was shown in Fig. 3 , from Fig. 1 (b) and Fig. 3 can be see that along with the prolongation of galvannealed time, the phase structure in galvannealed coating was changed as: $\eta \rightarrow \eta+\zeta+\delta_{1 \mathrm{p}} \rightarrow \eta+\zeta+\delta_{1 \mathrm{p}}+\delta_{1 \mathrm{k}} \rightarrow \zeta+\delta_{1 \mathrm{p}}+\delta_{1 \mathrm{k}}$ $\rightarrow \delta_{1 \mathrm{p}}+\delta_{1 \mathrm{k}}+\Gamma_{1} \rightarrow \delta_{1 \mathrm{k}}+\Gamma_{1}$. When the galvannealed time were $60 \mathrm{~s}$ and $90 \mathrm{~s}$, here were lots of random shape $\zeta$ phase in the part of coating, and the corrosion resistance of galvannealed coating had a little changed because of the increase of complex phase and Fe content.

When the galvannealed time was $120 \mathrm{~s}$, there was some columnar crystals $\delta_{1 \mathrm{p}}$ phase which 
perpendicular to the steel substrate and coating interface approximately at the coating section near the surface, but at the site near the steel substrate, there was some random orientation connected $\delta_{1 \mathrm{k}}$ phase. And the corrosion potential was increased to $-0.994 \mathrm{~V}$, corrosion rate was descended to $3.34 \times 10^{-4} \mathrm{~g} / \mathrm{m}^{2} \mathrm{~h}$, and the corrosion resistance of galvannealed coating was increased. When the galvannealed time increased to $150 \mathrm{~s}$, all coating section was occupied by the compact $\delta_{1 \mathrm{k}}$ phase, which near the steel substrate and coating interface, there was a thin $\Gamma_{1}$ phase between the steel substrate and coating. The coating was mainly conposed by $\delta_{1}$ phase, because the $\Gamma_{1}$ phase was very thin, and the corrsion resistance of galvannealed coating had increase. When the galvannealed time increased to $180 \mathrm{~s}$, the galvannealed coating was mianly comprised by a compact entire $\delta_{1 \mathrm{k}}$ phase, and there was a thin tooting structure which was $\Gamma_{1}$ phase. So when the galvannealed times was 180s, the galvannealed coating had a good corrosion resistance. However, along with the prolongation of galvannealed time, the corrosion resistance of galvannealed coating became good, especially when the $\Gamma_{1}$ phase appeared.

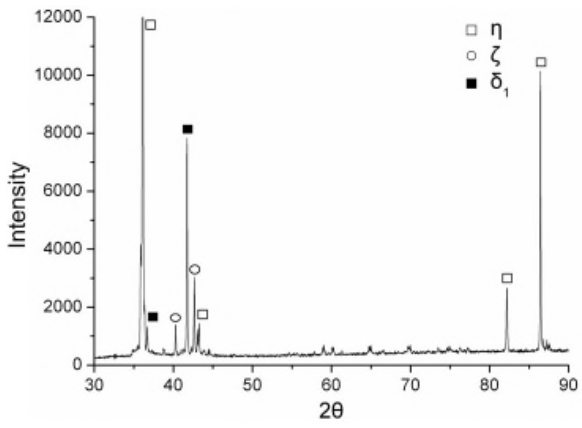

(a) $60 \mathrm{~s}$

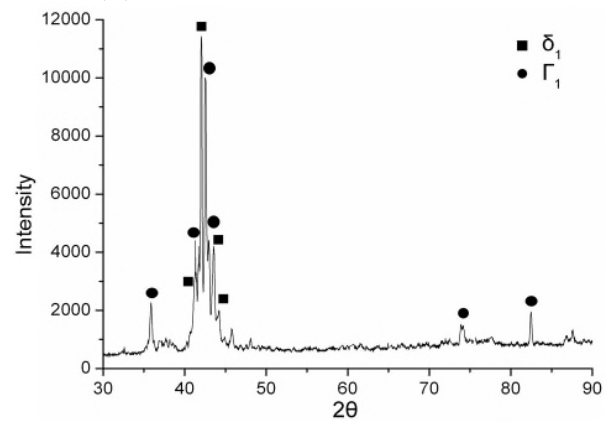

(d) $150 \mathrm{~s}$

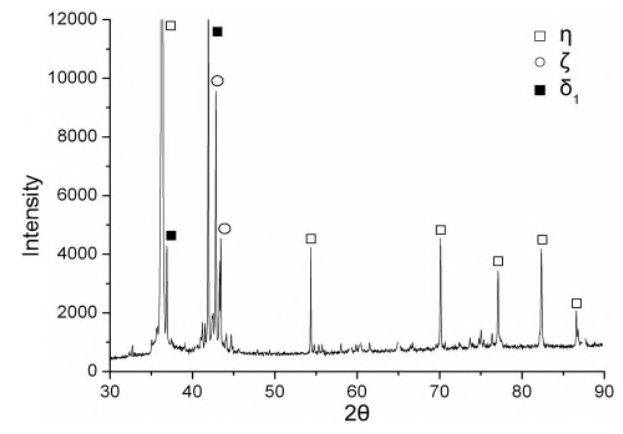

(b) $90 \mathrm{~s}$

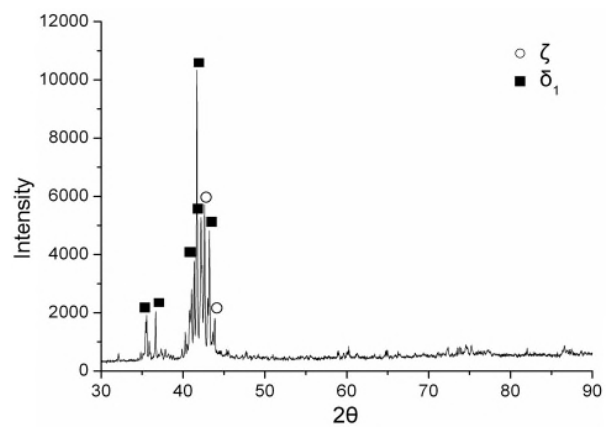

(c) $120 \mathrm{~s}$

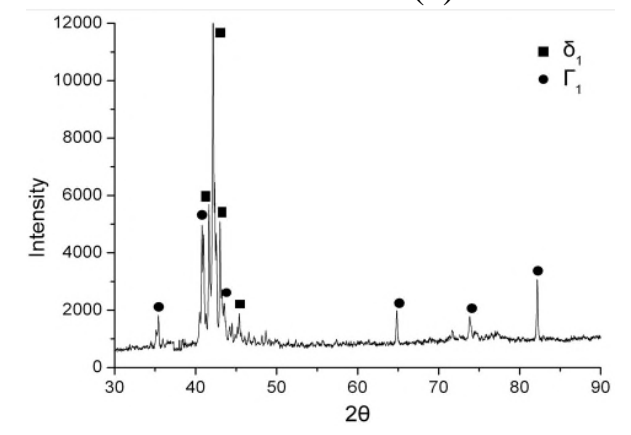

(e) $180 \mathrm{~s}$

Fig. 3 X-ray diffraction patterns of different phases structure in galvannealed coating with different galvannealed time at $500{ }^{\circ} \mathrm{C}$ (a) 60s, (b) $90 \mathrm{~s}$, (c) $120 \mathrm{~s}$, (d) $150 \mathrm{~s}$, (e) $180 \mathrm{~s}$.

When the galvannealed temperature was $550{ }^{\circ} \mathrm{C}$, the galvannealed time was $5 \mathrm{~s}, 10 \mathrm{~s}, 15 \mathrm{~s}, 20 \mathrm{~s}$ and 25 s respectively, the result of electrochemical analysis was shown in Fig. 1 (c). As can be seen from Fig. 1 (c) that when the galvannealed temperature was $550{ }^{\circ} \mathrm{C}$, along with the prolongation of galvannealed time, the corrosion potential increased, corrosion rate decreased, and corrosion resistance increased.

When the galvannealed temperature was $550{ }^{\circ} \mathrm{C}$, along with the prolongation of galvannealed time, the phase structure in galvannealed coating was change as: $\eta \rightarrow \eta+\zeta+\delta_{1 \mathrm{p}} \rightarrow \eta+\delta_{1 \mathrm{p}}+\delta_{1 \mathrm{k}}+\Gamma_{1} \rightarrow$ $\delta_{1 \mathrm{k}}+\Gamma_{1}$. When the galvannealed time was $5 \mathrm{~s}$, there were lots of random stylolitic shape $\zeta$ phase and massive $\delta_{1 \mathrm{k}}$ phase in galvannealed coating, and the corrosion potential was $-0.990 \mathrm{~V}$, corrosion rate was $5.01 \times 10^{-4} \mathrm{~g} / \mathrm{m}^{2} \mathrm{~h}$. When the galvannealed time was $5 \mathrm{~s}$ and $10 \mathrm{~s}$, most of the galvannealed coating was occupied by compact $\delta_{1 \mathrm{k}}$ phase, only a loose $\delta_{1 \mathrm{p}}$ phase structure near the surface and a thin toothing $\Gamma_{1}$ phase near the steel substrate and coating interface, and the corrosion potential of galvannealed coating increased to $-0.996 \mathrm{~V}$. When the galvannealed time increased to $20 \mathrm{~s}$ and $25 \mathrm{~s}$, the coating was comprised by a compact entire $\delta_{1 \mathrm{k}}$ phase, and there was a thin tooting structure which was compact $\Gamma_{1}$ phase. The corrosion potential and corrosion resistance of galvannealed coating increased obviously. So when the temperature was $550{ }^{\circ} \mathrm{C}$, the corrosion resistance of 
coating would be increased with the increase of galvannealed time. The formation of $\Gamma_{1}$ phase in galvannealed coating could improve the corrosion resistance of the coating effectively.

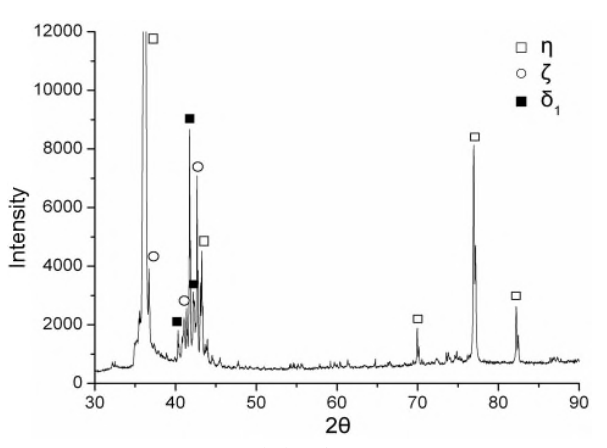

(a) $5 \mathrm{~s}$

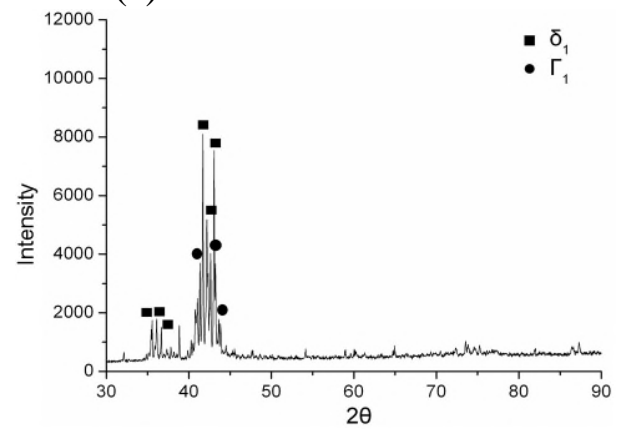

(d) $20 \mathrm{~s}$

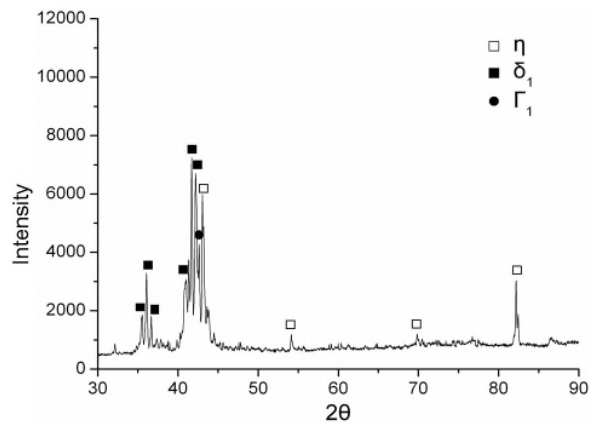

(b) $10 \mathrm{~s}$

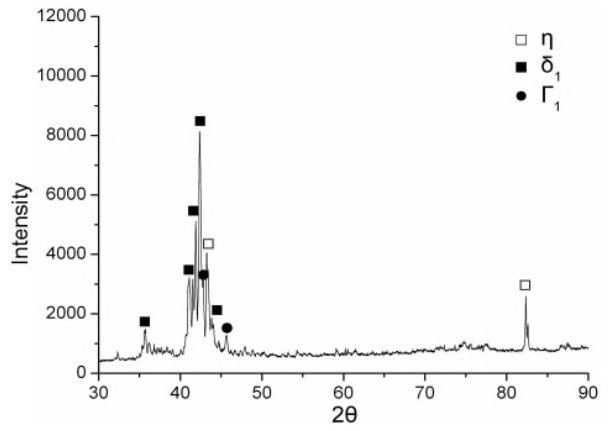

(c) $15 \mathrm{~s}$

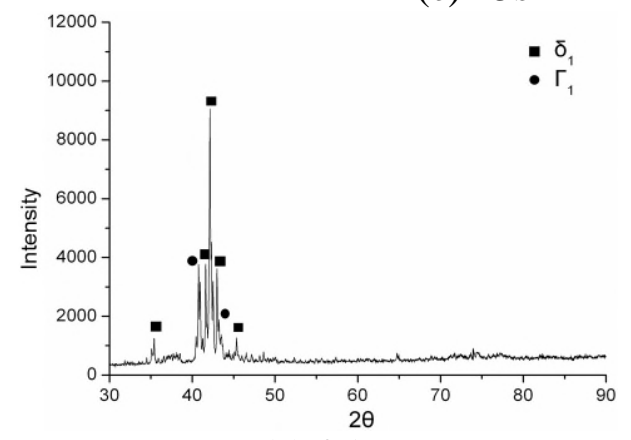

(e) $25 \mathrm{~s}$

Fig. 4 X-ray diffraction patterns of different phases structure in galvannealed coating with different galvannealed time at $550{ }^{\circ} \mathrm{C}$, (a) $5 \mathrm{~s}$, (b) $10 \mathrm{~s}$, (c) $15 \mathrm{~s}$, (d) $20 \mathrm{~s}$, (e) $25 \mathrm{~s}$.

From Fig. 1 (a) and Fig. 1 (b) can be seen that when the galvannealed time of high-strength IF galvanized steel sheet was $120 \mathrm{~s}$ at $450{ }^{\circ} \mathrm{C}$, the self-corrosion potential of galvannealed coating was $-0.991 \mathrm{~V}$. But when the galvannealed temperature was $500{ }^{\circ} \mathrm{C}$, the self-corrosion potential of galvannealed coating was $-0.985 \mathrm{~V}$, which was higher than the galvanized steel sheet galvannealed at $450{ }^{\circ} \mathrm{C}$. When the galvannealed temperature was $450{ }^{\circ} \mathrm{C}$, the self-corrosion current of galvannealed coating was $0.067 \mathrm{~mA} / \mathrm{cm}^{2}$, which more than $500{ }^{\circ} \mathrm{C}$, that self-corrosion current was $0.030 \mathrm{~mA} / \mathrm{cm}^{2}$, and the corrosion rate was $8.00 \times 10^{-4} \mathrm{~g} / \mathrm{m}^{2} \mathrm{~h}$ at $450{ }^{\circ} \mathrm{C}$, which also more than $500{ }^{\circ} \mathrm{C}$, that corrosion rate was $3.58 \times 10^{-4} \mathrm{~g} / \mathrm{m}^{2} \mathrm{~h}$. So the corrosion resistance of coating that galvannealed at $500{ }^{\circ} \mathrm{C}$ was better than galvannealed at $450{ }^{\circ} \mathrm{C}$.

From Fig. 1 (b) and Fig. 1 (c) can be seen that when the galvanized coating was galvannealed at $500{ }^{\circ} \mathrm{C}$ and $550{ }^{\circ} \mathrm{C}$, the corrosion resistance of galvannealed coating was batter, when the galvannealed temperature was $550^{\circ} \mathrm{C}$, in the short time $(5 \mathrm{~s})$, the corrosion potential of galvannealed coating was higher, when the galvannealed temperature was $550{ }^{\circ} \mathrm{C}$ than $500{ }^{\circ} \mathrm{C}$, and the corrosion rate of galvannealed coating was lower, when the galvannealed temperature was $550{ }^{\circ} \mathrm{C}$ than $500{ }^{\circ} \mathrm{C}$. So compared with the corrosion resistance of galvanized coating that galvannealed at different temperature, the self-corrosion potential of galvannealed coating increased, self-corrosion current and corrosion rate descended, and the corrosion resistance of galvannealed coating increased along with the prolongation of galvannealed time at the same galvannealed temperature.

Influence of Fe Content on the Corrosion Resistance. The relationship of corrosion potential and $\mathrm{Fe}$ content and the relationship of corrosion rate and $\mathrm{Fe}$ content at different galvannealed temperature was shown in the Fig. 5 and Fig. 6, from Fig. 5 and Fig. 6 can be see that the corrosion potential of galvannealed coating had little change, which approached the corrosion potential $(-1.098 \mathrm{~V})$ of pure zinc, when the Fe content of galvannealed coating was low, such as the Fe content was $8.69 \%$ at $450{ }^{\circ} \mathrm{C}$, the $\mathrm{Fe}$ content was $10.81 \%$ at $500{ }^{\circ} \mathrm{C}$ and the $\mathrm{Fe}$ content was $11.4 \%$ at $550{ }^{\circ} \mathrm{C}$. When the $\mathrm{Fe}$ content in galvannealed coating reached a certain value, the corrosion potential of galvannealed coating became high obviously. From Fig. 5 and Fig. 6 can be see that the corrosion rates of galvannealed coating descended along with the increase of Fe content at different 
galvannealed temperature, and the corrosion resistance of galvannealed coating increased along with the increase of Fe content.

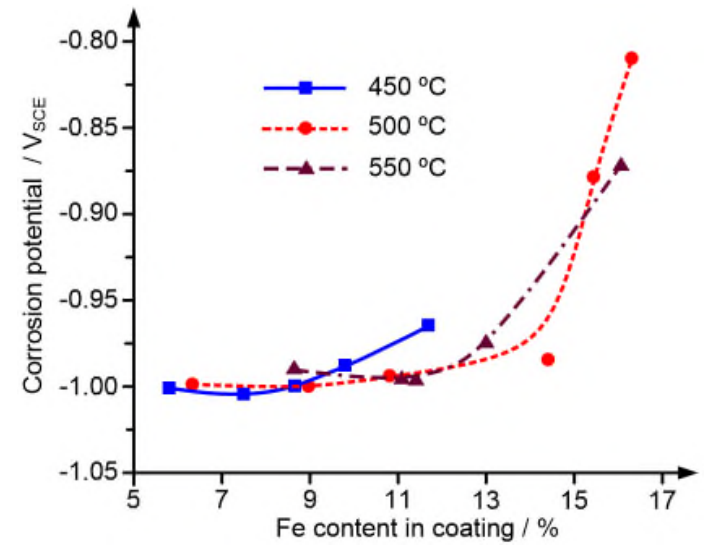

Fig. 5 The relationship of corrosion potential and $\mathrm{Fe}$ content.

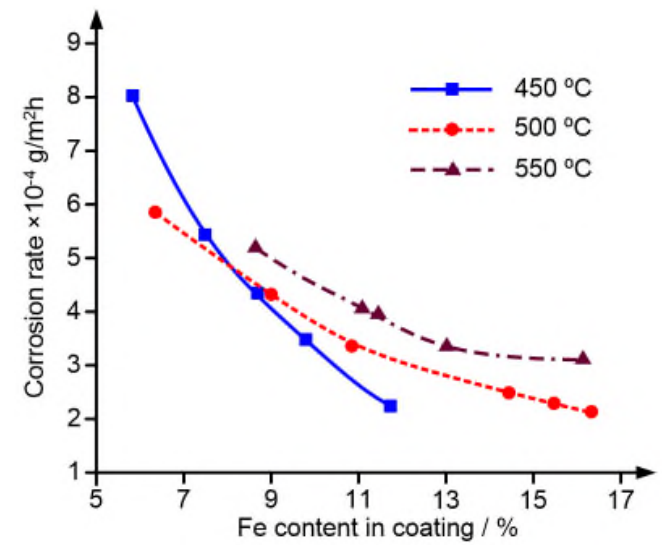

Fig. 6 The relationship of corrosion rate and Fe content.

\section{Conclusions}

(1) The corrosion resistance of galvannealed coating was influenced by the galvannealed temperature and time obviously. Along with the prolongation of galvannealed time, the corrosion resistance of galvannealed coating became batter at the same galvannealed time. And the corrosion resistence of galvannealed coating became excellent, along with the increase of the galvannealed temperature

(2) The corrosion resistance of galvannealed coating was different, when the galvannealed coating had different phase structure, when the compact $\Gamma$ phase formed in galvannealed coating, the galvannealed coating had an excellent corrosion resistance greatly.

(3) The corrosion resistance of galvannealed coating became excellent along with the increased of Fe content in coating.

\section{Acknowledgement}

In this paper, the research was sponsored by the National Nature Science Foundation of China (Project No. 51071052) and National High Technical Research and Development Program of China (Project No. 2012BAJ13B03).

\section{References}

[1] Q. F. Zhang, B. J. Liu, J. H. Huang. Modern Continuous Hot-Dip Galvanizing of Steel Sheets. Beijing: Metallurgical industrial press, 2007.

[2] M. Sagiyama, A. Hiraya, T. Watanabe, Electrochemical Behavior of Electrodeposited Zinc-Iron Alloys in Alkaline Solutions. J. Iron Steel Inst. 77 (1991) 251-257.

[3] M. Y. Gu, A. R. A. Marder, New Method to Fabricate Single $\delta$ phase Zn-Fe coating, Plating and Surface Finishing, 178(1) (1991) 77-79.

[4] X. Liu, S. M. Jiang, X. H. Yuan, et al. Corrosion-resistence Properties of Hot-Dip Galvannealed Steel sheets, Corr. Protect. 30(11) (2009) 768-771.

[5] X. H. Yuan, X. Liu, Q. F. Zhang. Quantitative Analysis of Phase Structure of Hot Galvanized Alloying Coatings, Mater. Protect. 44(01) (2011) 71-74.

[6] D. W. Guo, X. H. Yuan, Y. Lin, et al. Electrochemistry Characteristics and Corrosion Resistance of Galvannealed Steel Sheet, Heat Treatment Met. 38(6) (2013) 100-104. 